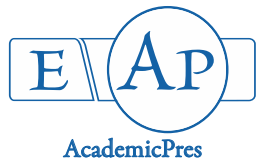

\title{
Molecular Level Investigation of Staphylococci's Resistance Mechanisms to Antibiotics
}

\author{
Lavinia L. PRUTEANU ${ }^{1 \#, 2,3 *}$, Lorentz J ̈̈NTSCHI ${ }^{2,4}$, \\ Cornelia CRĂCIUNAȘ ${ }^{5}$ \\ ${ }^{1 *}$ University of Cambridge, Centre for Molecular Science Informatics, Department of Chemistry, Lensfield Road, \\ Cambridge CB2 1EW, UK; llp25@cam.ac.uk ("current affiliation) \\ ${ }^{2}$ Babeş-Bolyai University, Institute for Doctoral Studies, 1 Kogălniceanu Street, 400084 Cluj-Napoca, \\ Romania; pruteanulavinia@gmail.com (*corresponding author) \\ ${ }^{3}$ University of Medicine and Pharmacy "Iuliu Hațieganu", MedFuture, Research Center for Advanced Medicine, 23 Gh. Marinescu/4-6 Pasteur \\ 400337, Cluj-Napoca, Romania; lavinia.pruteanu@umfluj.ro \\ ${ }^{4}$ Technical University of Cluj-Napoca, Department of Physics and Chemistry, 103-105 Muncii Blvd., 400641 Cluj-Napoca, \\ Romania; lorentz.jantschi@gmail.com \\ ${ }^{5}$ Babeş-Bolyai University, Faculty of Biology and Geology, Department of Experimental Biology, 5-7 Clinicilor, 400006 Cluj-Napoca, \\ Romania; craciunascornelia@gmail.com
}

\begin{abstract}
Polymerase chain reaction (PCR) techniques development allows the elaboration of many assays for identification of bacteria's resistance mechanisms to antibiotics. Following this idea, the results of molecular level investigation of bacteria's resistance mechanisms to antibiotics may give many opportunities to find more rapid methods for identifying the genes which are responsible for antibiotic resistance induction. The aim of the current study was to investigate antibiotic resistance genes in Staphylococcus bacteria on molecular level. Among classes of antibiotics, macrolides-lincosamides-streptogramin B (MLSB) and beta-lactams were used. In the proposed study, the bacterial strains were represented by 50 isolates of Staphylococcus. The bacterial strains were analyzed using polymerase chain reaction to identify the nuc, tuf, tst, sea, pathogenic activity genes. Thereafter, the bacteria were tested for $\operatorname{erm} A, \operatorname{erm} B$, erm $C$ genes and for $m e c A$, fem $A$ which are involved in the resistance to macrolides, lincosamides, streptogramin $\mathrm{B}$ and to beta-lactams, respectively. The presence or the absence of these genes confirmed that tested strains are resistant to specific antibiotic or not. Bacteria pathogenic activity was emphasized by genes as follows: sea (enterotoxin) which was found at all isolates, tst (toxic shock toxin) gene was not detected in any of the isolates and tuf gene (elongation factor) was obtained with one pair of primers. Resistance to beta-lactams was evidenced by the presence of $m e c A$ in all isolates and $\operatorname{fem} A$ in some strains. Each of erm $C$, erm $A$ and ermB, macrolides-lincosamides-streptogramin B resistance genes, was detected.
\end{abstract}

Keywords: bacterial resistance to antibiotics, beta-lactams, molecular level investigation, pathogenic activity genes, Staphylococcus bacteria

Abbreviations: BHI - Brain Heart Infusion, MLSB - Macrolides-Lincosamides-Streptogramin B, MRSA - Methicillin Resistant Staphylococcus aureus, MRS - Methicillin Resistant Staphylococcus, NCBI - National Center for Biotechnology Information, PCR - Polymerase Chain Reaction, DNA - Deoxyribonucleic Acid, dNTP - Deoxynucleotide

\section{Introduction}

Due to the attribute of Staphylococcus bacteria of rapidly multiplication, these pathogens can cause a variety of human and animal diseases.

The rapid raising of bacterial pathogens which present resistance to antibiotics (Ferry et al., 2009) has prompted the urgent need to find rapid methods of investigating bacterial resistance. Currently, molecular methods tend to become the most efficient approaches in identifying bacterial genes responsible for antibiotic resistance induction. Overtime, analyses of pathogens responsible for nosocomial infections are involved in comparing the resistance phenotypes of bacterial strains. For example 
308

Gould et al. (2010) presented the multiple antibiotic resistance profiles tested against 14 antimicrobial drugs and in another study, Saderi et al. (2011) presented their work based on determination of the prevalence of macrolide, lincosamide and streptogramin B (MLSB) phenotypes and genotypes in erythromycin-resistant strains of Staphylococcus. Also, in order to analyse the pathogens responsible for nosocomial infections, Naber (2008) describeed a method by which biotypes and serotypes can be compared with antimicrobial susceptibility profiles. Molecular techniques and DNA (deoxyribonucleic acid) analysis became popular based on the ability of displaying increased time efficiency (Nakipoglu et al., 2012).

By using PCR (polymerase chain reaction) methods and gene specific primers, it can be identified the bacterial genes responsible for resistance to different antibiotics and diagnose in time efficiently the bacterial infections (Singh $e t$ al., 2006; Francois and Schrenzel, 2008).

Singh (2006) also sustained that the molecular methods as well as microbial genotyping has been found to be medically useful and economically justified. According to Francois (2008), respectively Baddour (2007), genetic advances have enabled the identification of the characteristics of clinical isolates in real-time. Likewise, the molecular techniques mostly based on polymerase chain reaction have been used for the rapid detection of bacterial strains resistant to antibiotics.

Accessory genome or dispensable genetic material of staphylococci bacteria contains virulence factors such as chromosomal cassettes (Donnio et al., 2005), pathogenicity islands (Che et al., 2014), genomic islands (Juhas et al., 2008), bacteriophages (Orlova, 2012), plasmids and transposons (Bennet, 2008). These contain the responsible genes for resistance to antibiotics, like mec $A$ gene which is responsible for resistance to methicillin (Singh et al., 2006; Ferry et al., 2009). Transmission of these mobile genetic elements of a staphylococci strain to another one is realized through horizontal gene transfer as described by Donnio $e t$ al. (2005). Methicillin resistant Staphylococcus (MRS) is considered the main cause of nosocomial infections prevalence. For instance, Francois (2008) detailed about understanding the epidemiology of Methicillin resistant Staphylococcus aureus (MRSA) and the relationship between genome content and virulence. Baddour (2007) confirmed in his study that MSRA strains have been implicated in serious infections and nosocomial infectious, the strains being detected with several conventional methods. Following the affirmation that MRSA is considered the main cause of nosocomial infections prevalence, Donnio (2005) demonstrated that in French hospitals, MRSA strains increased until that time of the study. As well as Dickinson (2000) confirmed that Staphylococcus aureus clinical isolates tend to be either very susceptible or very resistant to methicillin.

Knowing all of these, a rapid detection of patients carrying methicillin resistant $S$. aureus, represents a must, so that MRSA transmission can be minimized. In this way, the diagnostic time of infection is reduced to 1 day instead of 2 or 4 days during standard methods (Saderi et al., 2011).

According to this data, using molecular level investigation, the study focused on the detection of pathogenic activity determined by nuc (thermonuclease), tuf (elongation factor), tst (toxic shock toxin), sea (enterotoxin) pathogenic activity genes (Samie et al., 2011; Alfatemi et al., 2014). One of the most important enzymes produced by Staphylococcus aureus is recognized as thermonuclease encoded by nuc gene, this being responsible of DNA degradation of host cells, demonstrated by Kuroda et al. (2001).

In order to identify bacterial species, were followed the genes responsible of pathogenic activity and also the presence of specific marker genes such as mec $A, \operatorname{fem} A$, erm $A$, ermB, erm C. These genes were investigated in many other studies for different isolated strains like in the research of Martineau et al. (2000) for $S$. aureus and S. epidermidis isolated from various countries. Even more, the genes mentioned were investigated on isolates from blood and urine specimens in Turkey (Aktas et al., 2007) or from unknown MRSA carriers (Harbarth et al., 2006). Other examples are presented as Crăciunaş et al. (2010) investigated mecA, fermA, ermA, ermB, erm $C$ on clinical isolates, and Zmantar et al. (2008) used for their investigation Staphylococcus aureus strains isolated from auricular infections.

Therefore, as according to the aim of the study, to investigate antibiotic resistance genes in Staphylococcus bacteria on molecular level, the first step was to detect the pathogenic activity determined by nuc, tuf, tst, sea. Further on, Staphylococcus bacteria resistance to betalactams was highlighted by determining the presence of mec $A$ and fem $A$ genes. For resistance detection to MLSB was followed the presence of erm $A$, ermB and erm $C$ resistance genes.

\section{Materials and Methods}

\section{Clinicalisolates}

A number of 50 staphylococcal strains were isolated from Clinical Hospital for Infectious Diseases in ClujNapoca, Romania, from different hospital sectors such as long-term health care facilities, medical wards and surgical intensive care unit by our collaborators from hospital. The strains that were collected between late year of 2013 and early year of 2014, included: $S$. aureus and coagulase negative staphylococci $S$. epidermidis, $S$. haemolyticus, $S$. hominis species. First, the molecular analysis was used in order to detect bacterial species with pathogenic activity determined by nuc, tuf, tst, sea genes following by the detection of genes responsible for resistance to betalactams and macrolide - lincosamide - streptogramin B antibiotics, mec $A, \operatorname{fem} A, \operatorname{erm} A, \operatorname{erm} B$ and erm $C$ genes, using the polymerase chain reaction.

The strains were kept in BHI (Brain Heart Infusion) semi-solid agar with $10 \%$ glycerol at $-80{ }^{\circ} \mathrm{C}$. For reconstitution of strains, after thawing, the strains were inoculated on Columbia blood agar with 5\% sheep blood and Chapman agar, as per suggested by Percival et al. (2004). The authors recommended this type of isolation to be used for Staphylococci strains from a variety of clinical specimens, which is in the context of the present study. According to Percival as well, the procedure followed an incubation period of $18-24$ hours at $35-37^{\circ} \mathrm{C}$. 


\section{PCR (Polymerase chain reaction)}

The bacterial suspension was prepared in an Eppendorf tube using $2 \mu \mathrm{l}$ as matrix for PCR amplification. The PCR protocol consisted in the preparation of a PCR mixture. In each PCR tube specific quantities were introduced (Table 1).

After centrifugation for one second, the tubes were introduced into a thermal cycler, where the amplification was performed using parameters as presented in Table 2 .

A thermal cycler is an apparatus which can be used for any thermal cycling reaction, most commonly being used to amplify segments of DNA. The advantage is that a thermal cycler offers temperature uniformity and distribution, modern versions of thermal cyclers being based on the Peltier effect (Jiang et al., 2012; Okuwaki and Yamaguchi, 2014) through which the high and low temperatures can be controlled (Fig. 1).

For this study was used a Gradient Palm-Cycler, Corbett Life Science thermal cycler, heated and cooled by eight Peltier devices (Fig. 1) at set parameters corresponding to one cycle, as presented in Table 2.

After this process, the amplicons have been separated and visualised on $1.5 \%$ agarose gel, stained with $500 \mathrm{ng} / \mu \mathrm{l}$ ethidium bromide. All these steps followed the McPherson's and Møller's protocol, (McPherson and Møller, 2001) and Roux (2003). The images were captured using Bio-Profil gel documentation system (Vilber Lourmat, Marne-La-Vallée Cedex 1, France).
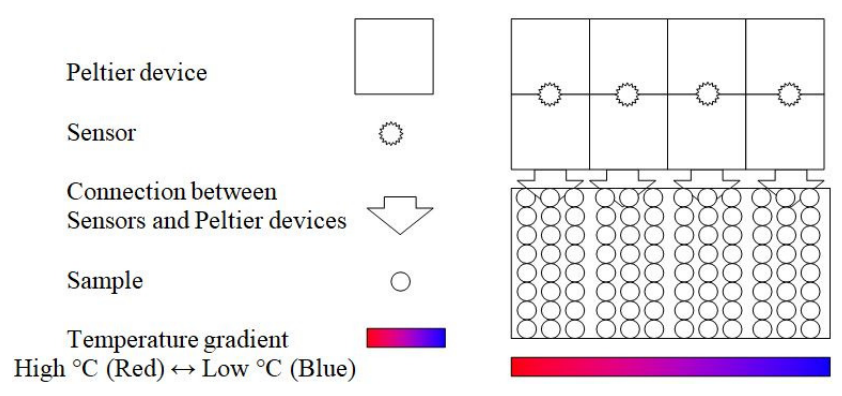

The primers (Table 3) were designed with the Primer programme, from DNA Sequence Analysis, according to the sequences found at NCBI (National Center for Biotechnology Information) data base.

The primers sequence were manually double checked in order to provide a higher accuracy for using the most optim ones. So as, for mecA it were considered the primers sequence 2 and 3 (Table 3 ).

For the amplification were used oligonucleotidic primers produced by Eurogentec S.A. Laboratories, Liege, Belgia; as molecular marker genes being used O'Range Ruler 100 DNA Ladder, SM1143 Fermentas kits.

\section{Results and Discussion}

During the experiment, sea was detected at all MRSA isolates (Fig. 2) while tst gene was not detected in any of the tested isolates. In several studies, authors aimed to detect the virulence genes like sea, tst as were considered for the current study. For example, Alfatemi et al. (2014) noted that among all tested isolates, 148 were detected as MRSA and from these ones the frequency of tst, sea genes was $11.64 \%$ and $27.39 \%$ respectively.

To be certain of the tst absence, the authors succeeded co-amplification with sea and nuc genes, in the same conditions and with the same reactives (Fig. 3).

The $t s t$ gene was not detected. Tuf gene was detected with the second pair of primers from Table 3 in almost all isolates (lane 15 - blank) (Fig. 4). Most frequent, tuf gene is identified in all tested isolates, confirming $S$. aureus presence (Samie and Shivambu, 2011). In the current study instead, the $t u f$ gene was not detected in one of the isolates.

MecA which is considered the principal gene responsible for MRSA (Singh et al., 2006; Ferry et al., 2009) was detected in all isolates species (100\%) (Fig. 5) while femA responsible for MRSA was not detected in any of the isolates (Fig. 6).

Fig. 1. Thermal cycler- Peltier effect

Table 1. PCR mixture

\begin{tabular}{cc}
\hline Compounds & Quantities $(\mu \mathrm{l})$ \\
\hline 10 x PCR reaction buffer & 5 \\
MgCl $50 \mathrm{mM}$ & 1.5 \\
$\mathrm{dNTP}($ Deoxynucleotide) Mix $10 \mathrm{mM}$ & 1 \\
Primer Fw (Forward) $(10 \mu \mathrm{M})$ & 1 \\
Primer Rv $($ Reverse) $(10 \mu \mathrm{M})$ & 1 \\
Taq polymerase* $(5 \mathrm{U} / \mu \mathrm{l})$ & 0.5 \\
Bacterial suspension (matrix) & 2 \\
Water UV/UP (sterile/ultrapure) (to $50 \mu \mathrm{l})$ & 37.1 \\
\hline
\end{tabular}

${ }^{*}$ Taq polymerase - enzyme isolated from the thermophilic bacterium Thermus aquaticus

Table 2. Parameters for PCR amplification

\begin{tabular}{lccc}
\hline \multicolumn{1}{c}{ Phase } & Time $(\mathrm{min})$ & Temperature $\left({ }^{\circ} \mathrm{C}\right)$ \\
\hline Initial denaturation & 5 & 95 \\
Denaturation & & 1 & 95 \\
Alignment & $30-36$ cycles & 1 & $45-62$ (depending on the primer) \\
Elongation & & 1 & 72 \\
Final elongation & & 10 & 72 \\
\hline
\end{tabular}


310

Table 3. Gene-specific primers

\begin{tabular}{|c|c|c|c|c|}
\hline Genes & Function & $\begin{array}{c}\text { Primers } \\
\text { Sequence } 5^{\prime} \rightarrow 3^{\prime}(\text { forward } / \text { reverse })\end{array}$ & $\begin{array}{l}\text { Amplicon size } \\
\text { (bp) }\end{array}$ & $\begin{array}{c}\text { NCBI } \\
\text { number }\end{array}$ \\
\hline \multirow{5}{*}{ mecA } & \multirow{5}{*}{ Resistance to meticilin } & 2.СТАТССТСТАGAAAAAGCGACTTCAC/ & 472 & \multirow{5}{*}{ NC002951 } \\
\hline & & AGTTGTAATCTGGAACTTGTTGAGC & & \\
\hline & & & & \\
\hline & & 3.TATGTTGGTCCCATTAACTCTGAAG/ & 450 & \\
\hline & & AGTTGAACCTGGTGAAGTTGTAATC & & \\
\hline \multirow{2}{*}{ nucA } & \multirow{2}{*}{ Thermonuclease } & GCGATTGATGGTGATACGGTT/ & \multirow{2}{*}{267} & \multirow{2}{*}{ EF529608 } \\
\hline & & AGCCAAGCCTTGACGAACTAAAGC & & \\
\hline \multirow{2}{*}{ tst } & \multirow{2}{*}{ Toxic shock toxin } & ATGGCAGCATCAGCTTGATA/ & \multirow{2}{*}{350} & \multirow[t]{2}{*}{ J02615 } \\
\hline & & TTTCCAATAACCACCCGTTT & & \\
\hline \multirow{5}{*}{ femA } & \multirow{5}{*}{ Resistance to meticilin } & $\begin{array}{l}\text { 1.Caggtaatgctggtaatgattgg/ } \\
\text { acggaatgcatttgatgtacc }\end{array}$ & 644 & \multirow{5}{*}{$\mathrm{NC} 007793$} \\
\hline & & 2.Cttactgctgtacctgttatgaaagtg/cattaccatgttcttcttgtagacg & 757 & \\
\hline & & 3. Gagttaaagcttgctgaaggttatg/ & & \\
\hline & & gtaagttatctcgcttgttatgtgc & 769 & \\
\hline & & $\begin{array}{l}\text { 4.Aacagctaaagagtttggtgcc/ } \\
\text { catcacgatcagcaaaagct }\end{array}$ & 647 & \\
\hline sea & Enterotoxin & ggatattgttgataaatataaagggaaaaaag/gttaatcgttttattatctctatatattcttaatagt & 439 & DQ6411670 \\
\hline \multirow{4}{*}{ tuf } & \multirow{4}{*}{ Elongation factor } & 1.GCCAGTTGAGGACGTATTCT/ & (1) & \multirow{4}{*}{ DQ414206 } \\
\hline & & ССАTTTCAGTACCTTCTGGTAA & 412 & \\
\hline & & & & \\
\hline & & $\begin{array}{l}\text { 2.baagagtttgatcctggctag/ } \\
\text { ttgaccgtgtctcagttcca }\end{array}$ & 320 & \\
\hline \multirow{2}{*}{ ermA } & \multirow{2}{*}{ Resistance to MLSB } & gaaccagaaaaaccctaaagacac/ & \multirow{2}{*}{513} & \multirow{2}{*}{$\mathrm{NC} 002952$} \\
\hline & & acagagtctacacttggcttaggatg & & \\
\hline \multirow{2}{*}{ ermB } & \multirow{2}{*}{ Resistance to MLSB } & GAAAAGGTACTCAACCAAATA/ & \multirow{2}{*}{639} & \multirow{2}{*}{ U35228 } \\
\hline & & AGTAACGGTACTTAAATTGTTTAC & & \\
\hline \multirow[t]{3}{*}{ erm $C$} & \multirow{3}{*}{ Resistance to MLSB } & 1.atatctttgaaatcggctcagg/ & 420 & \multirow{3}{*}{ NC007792 } \\
\hline & & gtgagctattcactttaggtttagg & & \\
\hline & & $\begin{array}{l}\text { 2. Cgtaactgccattgaaatagacc/ } \\
\text { gtgagctattcactttaggtttagg }\end{array}$ & 356 & \\
\hline
\end{tabular}

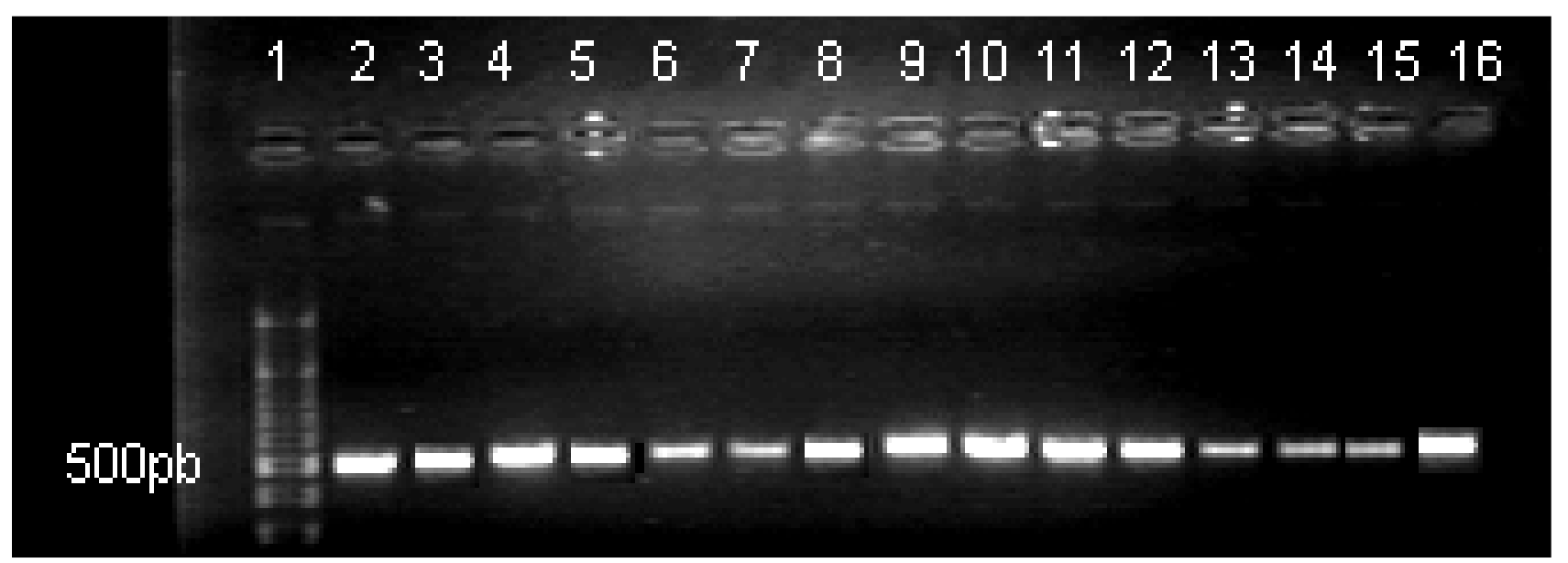

Fig. 2. Agarose gel electrophoresis of PCR products after amplification of sea genes (lanes 2-16) (10 $\mu \mathrm{l} /$ lane); lane 1-molecular marker (O’Range Ruler 100 DNA Ladder, SM1143 Fermentas). 500 bp (base pairs) lane was marked 


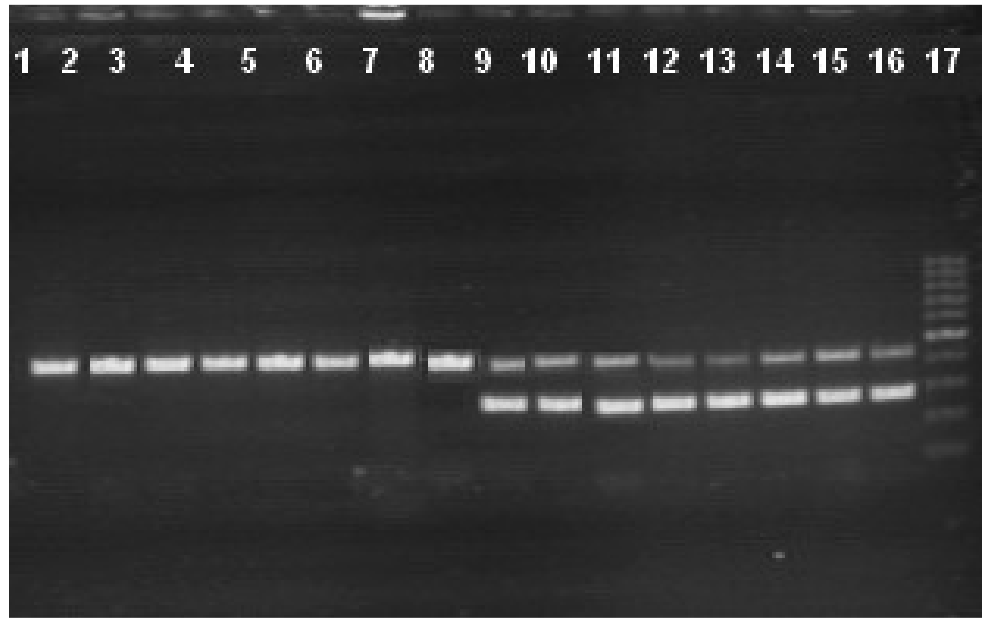

Fig. 3. Agarose gel electrophoresis of PCR products after amplification of sea + tst and $n u c+$ sea genes (10 $\mu \mathrm{l} /$ lane); lanes: 1-9 sea gene products; 10-16 amplification products of sea + nuc genes; lane 17 - molecular marker (O'Range Ruler 100 DNA Ladder, SM1143 Fermentas)

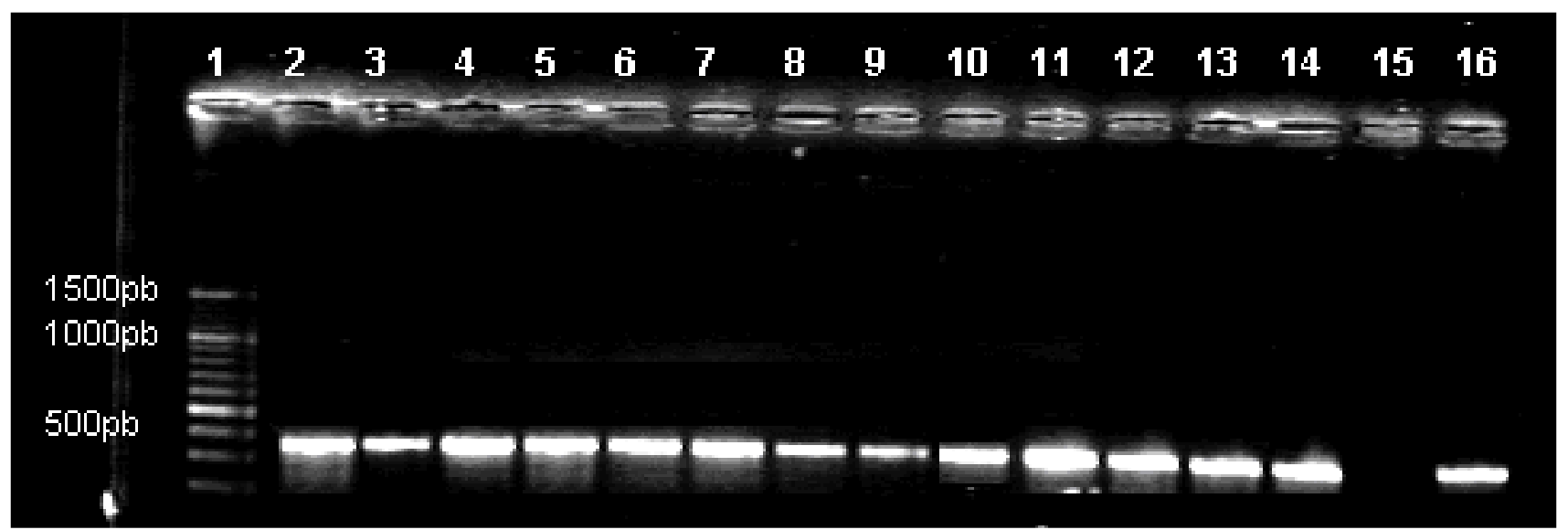

Fig. 4. Agarose gel electrophoresis of PCR products after amplification of tuf gene ( $10 \mu \mathrm{l} /$ lane); lanes: 2 - 14 and 16 amplification products for tuf with second pair of primers; lane 15- blank; lane 1 - molecular marker (O'Range Ruler 100 DNA Ladder, SM1143-Fermentas); 500 bp, 1000 bp and 1500 bp lanes were marked

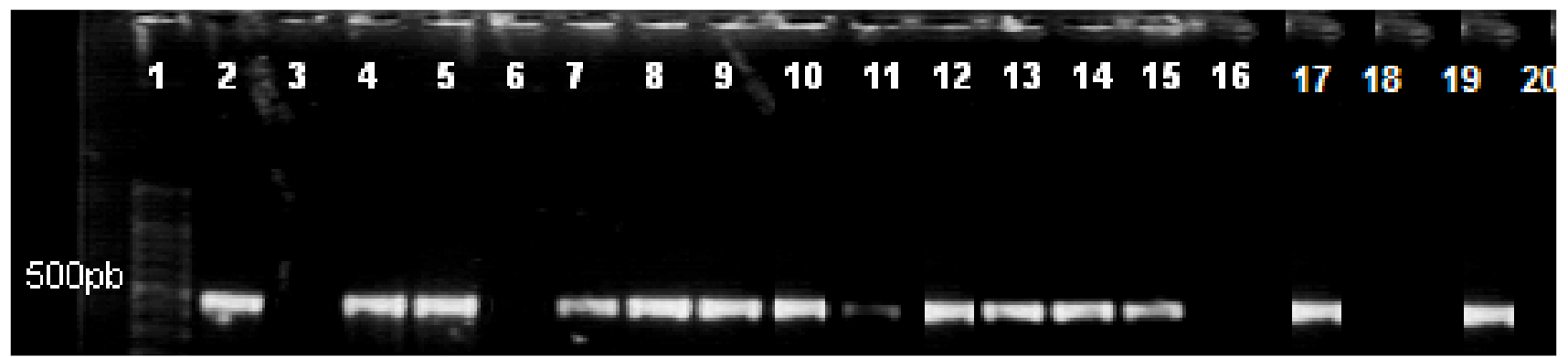

Fig. 5. Agarose gel electrophoresis of PCR products after amplification of mec $A$ gene at $S$. aureus (lanes 2-6) (10 $\mu \mathrm{l} /$ lane) and at $S$. epidermidis (lanes 7-16) (10 $\mathrm{l}$ /lane); lane 1 - molecular marker (O’Range Ruler 100 DNA Ladder, SM0623-Fermentas); 500 bp lane was marked

Even though, it is well known that fem $A$ gene exists in $S$. aureus and is absent in coagulase negative staphylococcus strains, the gene being successfully considered for detection of MRSA (Oshima et al., 1993; Liu et al., 2016), the results showed in this case that ferm $A$ gene was not detected in any of the isolates tested.

$E r m C, e r m A$ and $e r m B$ associated with MLSB resistance, were detected as follows: erm $C$ gene at 23 strains (Fig. 7), erm $A$ gene at 12 strains (24\%) (Fig. 8) and $\mathrm{ermB}$ gene was detected at 6 strains (12\%) (Fig. 9). In literature, erm $C$ is often identified at staphylococci strains in proportion of $45-80 \%$ meaning that this gene is responsible for the majority of resistance bacteria to MLSB antibiotics (Martineau et al., 2000; Aktas et al., 2007). The statement is supported as well by the hereby obtained results, where erm $C$ gene was found as being predominant at 23 strains (46\%) from the tested isolates. 
312

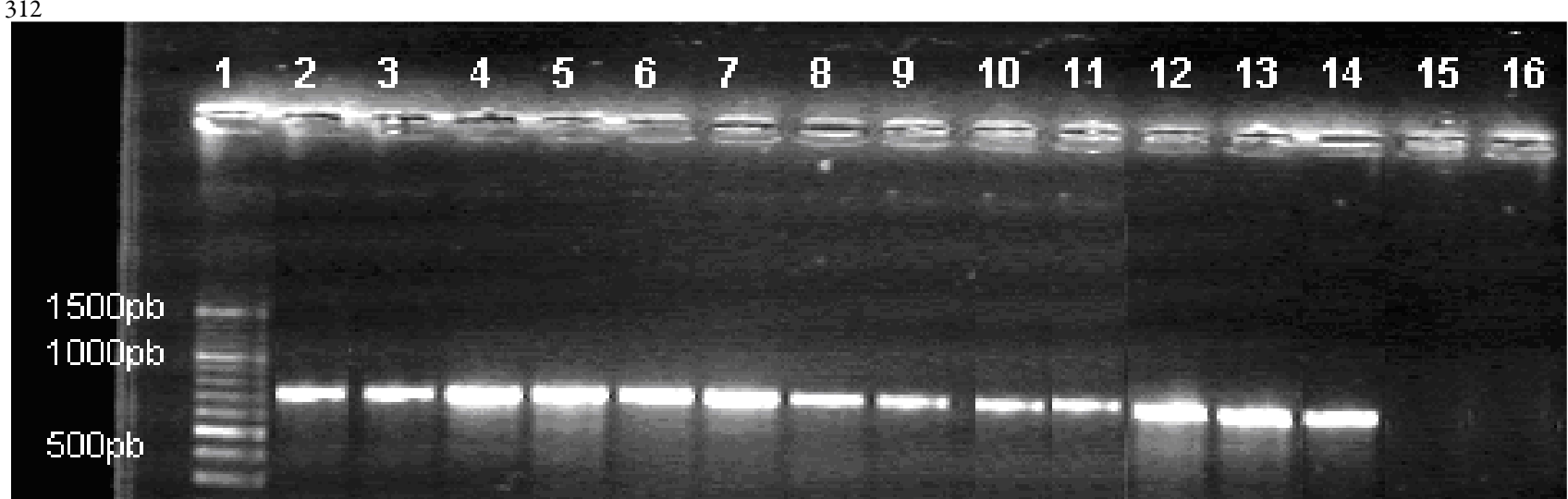

Fig. 6. Agarose gel electrophoresis of PCR products after amplification of fem $A$ at $S$. aureus (lanes 2 - 14) (10 $\mu \mathrm{l} /$ lane); lane 1 molecular marker (O’Range Ruler 100 DNA Ladder, SM0623 Fermentas); 500 bp, 1000 bp and 1500 bp lanes were marked

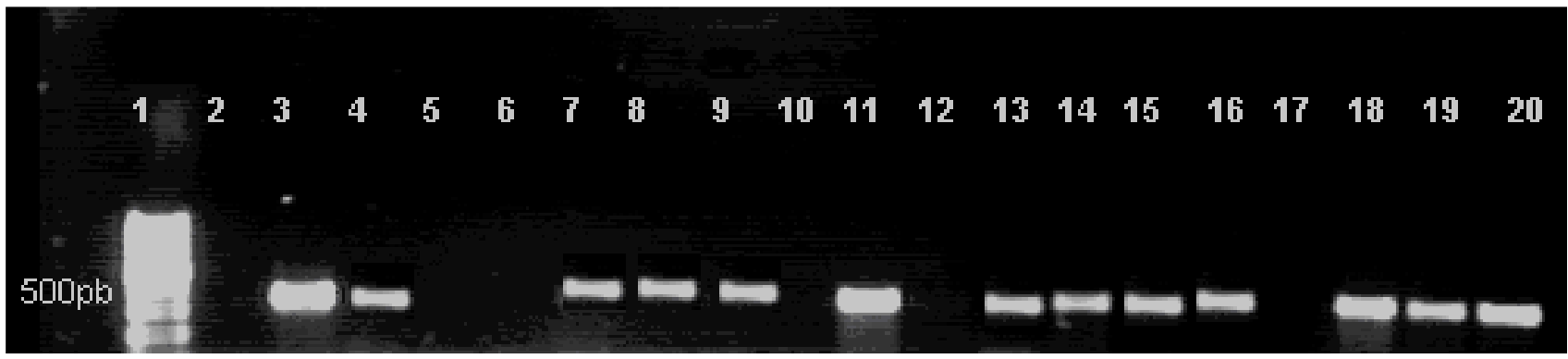

Fig. 7. Agarose gel electrophoresis of PCR products after amplification of $\mathrm{erm} C$ gene (lanes 2-20, $10 \mu \mathrm{l} /$ lane) at $S$. aureus; lane 1 molecular marker (O’Range Ruler 100 DNA Ladder, SM0623-Fermentas); 500 bp lane was marked

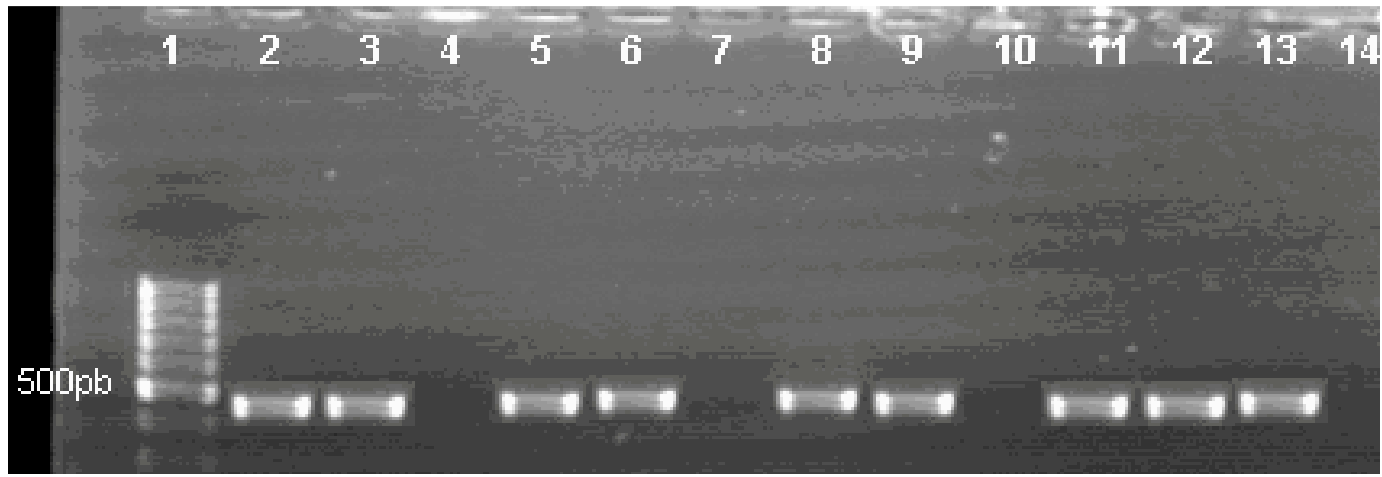

Fig. 8. Agarose gel electrophoresis of PCR products after amplification of ermA gene at $S$. aureus (lanes 2-4, 12 and 14) (10 $\mu \mathrm{l} /$ lane), S. hominis (lanes 5, 6 and 11), S. haemolyticus (lanes 7 and 10), S. epidermidis (lanes 8, 9 and 13); lanel 1 -molecular marker (O’Range Ruler 100 DNA Ladder, SM1203-Fermentas); 500 bp lane was marked

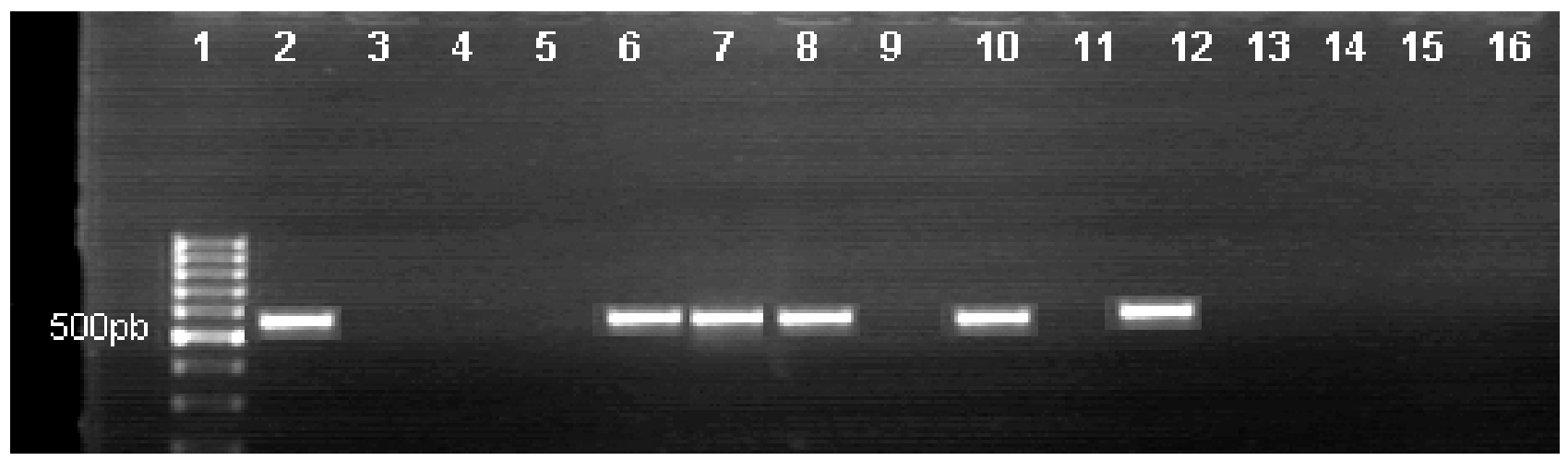

Fig. 9. Agarose gel electrophoresis of PCR products after amplification of ermB gene at $S$. aureus (lanes 2-3) (10 $\mu \mathrm{l} / \mathrm{lane}), S$. epidermidis (lanes 4 - 16); lane 1 -molecular marker (O’Range Ruler 100 DNA Ladder, SM1203-Fermentas); 500 bp lane was marked 
The PCR method was used to identify the genes which give resistance to different antibiotics and also the genes responsible for pathogenic activity.

In comparison with other studies such as the ones mentioned for each gene in the description above, the current results show that the mentioned genes are identified approximately in a similar number as can be found in literature (Harbarth et al., 2006; Zmantar et al., 2008; Crăciunaş et al., 2010).

With these obtained results, the author can sustain the assertion that the main $S$. aureus genes involved in the resistance to antibiotics for the studied isolates are: $\operatorname{mec} A$, ferm $A$, erm $A$, ermB and erm $C$.

\section{Conclusions}

Analyses of pathogenic activity genes for the 50 staphylococcal strains revealed the presence of $n u c, t u f$ and sea genes acting as thermonuclease, elongation factor and enterotoxin. It was not detected the tst gene, which means that, in this case, pathogenic activity was not caused by toxic shock toxin. Among the Staphylococcus isolates, resistance to MLSB antibiotics was expressed by finding erm $A$ gene at 12 strains (24\%), ermB at $6(12 \%)$ strains, erm C at $23(46 \%)$ strains while the resistance to beta-lactams was expressed in proportion of $100 \%$ by $m e c A$, although fem $A$ genes were not detected in any of the MRSA isolates.

\section{Acknowledgements}

The current research received no specific grant from any funding agency in the public, commercial, or not-for-profit sectors.

L.L.P. acknowledges Andreas Bender for the support provided as a visiting researcher at the Centre for Molecular Science Informatics of the Department of Chemistry of the University of Cambridge.

\section{References}

Aktas Z, Aridogan A, Kayacan CB, Aydin D (2007). Resistance to macrolide, lincosamide and streptogramin antibiotics in Staphylococci isolated in Istanbul, Turkey.Journal of Microbiology 45(4):286-290..

Alfatemi SMH, Motamedifar M, Hadi N, Saraie HSE (2014). Analysis of virulence genes among methicillin resistant Staphylococcus aureus (MRSA) strains.JundishapurJournal of Microbiology 7(6):e10741..

Baddour MM, AbuElKheir MM, Fatani AJ (2007). Comparison of mecA polymerase chain reaction with phenotypic methods for the detection of methicillin-resistant Staphylococcus aureus. Current Microbiology 55(6):473-479.

Bennet PM (2008). Plasmid encoded antibiotic resistance: acquisition and transfer of antibiotic resistance genes in bacteria. British Journal of Pharmacology 153(Suppl 1):S347-S357.

Che D, Hasan MS, Chen B (2014). Identifying pathogenicity islands in bacterial pathogenomics using computational approaches. Pathogens 3:36-56.
Crăciunaş C, Butiuc-Keul A, Flonta M, Almaş A, Brad A, Sigarteu M (2010). Development of a PCR assay for identification of antibiotic resistance determinants at Staphylococcus aureus. Analele Universității din Oradea-Fascicula Biologie Tom XVII(2):248-252.

Dickinson TM, Gordon AL (2000). Phenotypic expression of oxacillin resistance in Staphylococcus epidermidis: Roles of mecA transcriptional regulation and resistant-subpopulation selection. Antimicrobial Agents and Chemotherapy 44:1616-1623.

Donnio PY, Oliveira DC, Faria NA, Wilhelm N, Le Coustumier A, De Lencastre H (2005). Partial excision of the chromosomal cassette containing the methicillin resistance determinant results in methicillin susceptible Staphylococcus aureus. Journal of Clinical Microbiology 43(8):4191-4193.

Ferry T, Etienne J (2009). Toxin-mediated syndromes. In: Crossley KB, Jefferson KK, Archer GL, Fowler VG (Eds). Staphylococci in human disease. Wiley-Blackwell (2thed), Oxford, UK pp 484496.

Francois P, Schrenzel J (2008). Rapid diagnosis and typing of Staphylococcus aureus. In: Lindsay J (Ed). Staphylococcus: Molecular Genetics. Caister Academic Press, Norfolk, UK pp 71-89.

GouldS, Cuschieri P, Rollason J,Hilton AC,Easmon S, Fielder MD (2010). The need for continued monitoring of antibiotic resistance patterns in clinical isolates of Staphylococcus aureus from London and Malta. Annals ofClinical Microbiology and Antimicrobials 9:20-20.

Harbarth S, Masuet-Aumatell C, Schrenzel J, Francois P, Akakpo C, Renzi G, Pugin J, Ricou B, Pittet D (2006). Evaluation of rapid screening and pre-emptive contact isolation for detecting and controlling methicillin resistant Staphylococcus aureus in critical care: an interventional cohort study. Critical Care 10(1):R25.

Jiang J, Kaigala GV, Marquez HJ, Backhouse CJ (2012). Nonlinear controller designs for thermal management in PCR amplification, IEEE Transactions on Control Systems Technology 20(1):11-30.

Juhas M, Roelof van der Meer J, Gaillard M, Harding RM, Hood DW, Crook DW (2008). Genomic islands: tools of bacterial horizontal gene transfer and evolution. Federation of European Microbiological Societies Microbiology Reviews 33(2009):376-393.

Kuroda M, Ohta T, Uchiyama I, Baba T, Yuzawa H, Kobayashi I (2001). Whole genome sequencing of methicillin-resistant Staphylococcus aureus. The Lancet357:1225-1240.

Martineau F, Picard FJ, Lansac N, Ménard C, Roy PH, Ouellette M (2000). Correlation between the resistance genotype determined by multiplex PCR assays and the antibiotic susceptibility patterns of Staphylococcus aureusandStaphylococcus epidermidis. Antimicrobial Agents and Chemotherapy 44(2):231-238.

McPherson MJ, Møller SG (2001). PCR - The basics. BIOS Scientific Publishing, Oxford 4:67-87.

Naber CK (2008). Future strategies for treating Staphylococcus aureus bloodstream infections. Clinical Microbiology and Infection 14(s2):2634 .

Nakipoglu Y, Ignak S, Gürler N, Gürler B (2012). The prevalence of antiseptic resistance genes ( $\mathrm{qac} A / \mathrm{B}$ and $\mathrm{smr}$ ) and antibiotic resistance in clinical Staphylococcus aureus strains. Mikrobiyoloji Bülteni 46(2):180-9. 
314

Okuwaki Y, Yamaguchi S (2011). A portable thermal cycler using a PN sandwich-structure Peltier device. Advanced Materials Research 54:128131.

Orlova EV (2012). Bacteriophages and their structural organisation. In: Kurtboke I (Ed). Bacteriophages. InTech, UK pp 3-30. Available from: http://www. intechopen.com/books/bacteriophages/bacteriophagesand-their-structural-organisation.

Oshima T, Miyachi H, Fusegawa H, Masukawa A, Ikeda M, Ando Y, Rinsho B (1993). Detection of methicillin-resistant Staphylococcus aureus by in vitro enzymatic amplification of $m e c A$ and fer $A$ genes. RinshoByori41(7):773-778.

Percival SL, Chalmers R, Embrey M, Hunter P, Sellwood J, Wyn-Jones P (2004). Microbiology of waterborne diseases. In: Percival SL(Ed). Other heterotrophic plate count bacteria: Flavobacterium, Klebsiella, Pseudomonas, Serratia, Staphylococcus. Elsevier Academic Press, UK pp 125-143.

Percival SL, Yates MV, Williams DW, Chalmers R, Gray NF (2014). Microbiology of waterborne diseases: Microbiological aspects and risks. In: Percival SL, Williams DW (Eds). Bacteriology. Elsevier Academic Press(2thed), UK pp 35-259.

Roux KH (2003). Optimization and troubleshooting in PCR In: Dieffenbach CW, Dveksler GS (Eds). PCR Primers: A Laboratory Manual. Cold Spring Harbor, NY: Cold Spring Harbor Laboratory pp $53-62$.
Saderi H, Emadi B, Owlia P (2011). Phenotypic and genotypic study of macrolide, lincosamide and streptogramin B (MLSB) resistance in clinical isolates of Staphylococcus aureus in Tehran, Iran. The Medical Science Monitor 17(2):BR48-53.

Samie A, Shivambu N (2011). Molecular detection of methicillin resistance gene (mec $A$ gene) and pathogenic genes among Staphylococcus aureus isolates from clinical and drinking water samples of HIV and AIDS patients in Limpopo Province, South Africa. African Journal of Microbiology Research 5(30):5498-5506.

Singh A, Goering RV, Simjee S, Foley SL, Zervos MJ (2006). Application of molecular techniques to the study of hospital infection. Clinical Microbiology Reviews 19:512-530.

Liu Y, Zhang J, Ji Y (2016). PCR-based approaches for the detection of clinical methicillin-resistant Staphylococcus aureus. The Open Microbiology Journal 10:45-56.

Zmantar T, ChaiebK, Ben Abdallah F, Ben Kahla-Nakbi A, Ben Hassen A, Mahdouani K, Bakhrouf A (2008). Multiplex PCR detection of the antibiotic resistance genes in Staphylococcus aureus strains isolated from auricular infections. Folia Microbiologica 53:357-362. 